\title{
MODAL BUDAYA “TIMMONG” SEBAGAI REKONSILIASI DAMPAK SOSIAL PASCA PILKADES DI KABUPATEN SUMENEP
}

\author{
Syaiful, Ria Kasanova, \& Sri Widjajanti \\ Universitas Madura \\ syaiful@unira.ac.id
}

\begin{abstract}
Abstrak:
Masyarakat Madura dikenal sebagai masyarakat yang komunal, ketat terhadap ajaran agama, berwatak keras suka bekerja keras dan pantang menyerah. Dalam dinamika kehidupan yang berkembang saat ini kontelasi perpolitikan juga turut memberikan pengaruh terhadap masyarakat Madura khususnya masyarakat Desa Batu Belah Barat, kecamatan Dasuk, kabupaten Sumenep dalam bentuk konflik sosial. Tradisi timmong merupakan tradisi masyarakat Desa Batu Belah Barat yang dilakukan secara turun temurun sebagai tradisi berdoa memohon turunnya hujan kepada Tuhan yang maha esa dalam bentuk tarian dan bunyi-bunyian lewat mulut atau verbal tanpa menggukan alat musik. Penelitian ini merupakan penelitian kualitatif. Sumber primer penelitian ini adalah narasumber yang diwawancarai, sedangkan sumber sekunder dalam penelitian ini berupa catatan dan referensi mengenai budaya Madura. Hasil penelitian ini menunjukkan dampak positif tradisi timmong sebagai rekonsiliasi konflik pasca pilkada di Desa Batu Belah Barat kecamatan Dasuk kabupaten Sumenep.
\end{abstract}

Kata Kunci: Budaya Timmong, Rekonsiliasi, Pilkades

\begin{abstract}
:
The Madurese community is known as a communal society, strict on religious teachings, hard-tempered, likes to work hard and never gives up. In the dynamics of life that is currently developing, the political controversy also has an influence on the Madurese community, especially the community in the village of Batu Belah Barat, Dasuk District, Sumenep Regency in the form of social conflicts. The timmong tradition is a tradition of the community in the western part of the stone which is carried out from generation to generation as a tradition of praying for rain to God Almighty in the form of dances and sounds by mouth or verbally without using musical instruments. This research is a qualitative research. The primary sources of this study were interviewed sources, while the secondary sources in this study were notes and references about Madurese culture. The results of this study indicate the positive impact of the timmong tradition as a reconciliation of post-election conflicts in the village of Batu Belah Barat sub-district Dasuk Sumenep district.
\end{abstract}

Keywords: Timmong Culture, Reconciliation, Pilkades 


\section{Pendahuluan}

Pulau Madura (Pulau Madura) terdiri dari empat wilayah, yaitu Bangkalan, Sampang, Pamekasan dan Sumenep di titik paling timur ${ }^{1}$. Sebagian besar masyarakat Madura tinggal di Pulau Madura dalam kelompok-kelompok kecil membentuk Desa pertanian ${ }^{2}$. Orang Madura hanya membudidayakan lahan sebagian kecil saja dengan baik, karena tanahnya sendiri ada terdiri dari dua jenis yaitu kering dan subur karena di madura ccuma terdiri dari dua musim yaitu musim hujan dan kemarau. Oleh karena itu, panen terbesar di setiap musim adalah padi dan tembakau. Namun demikian, tidak sedikit masyarakat Madura yang juga menjadi nelayan, petani garam dan pengrajin senjata tajam tradisional (dapur, alat pertanian dan alat-alat buatan tangan) ${ }^{3}$.

Orang Madura memiliki sifat dan gaya hidup yang sangat ketat antara satu dengan yang lainnya dan tidak sama dengan daerah-daerah lain, dan salah satu faktor yang melatar belakangi itu semua terkait adalah kondisi alamnya yang cukup keras. Kekerasan dan keyakinan agama selalu dekat dengan citra simbolis masyarakat Madura (agamis). Kedua kosakata tersebut memiliki arti yang berbeda bahkan persilangan di antara keduanya. Seseorang yang akrab dengan dunia kekerasan dalam hidupnya akan jauh dari terpuji dan tidak layak untuk ditiru. Di sisi lain, umat beragama selalu memiliki sikap yang baik terhadap kehidupan dan menjauhi anarki dan kekerasan ${ }^{4}$.

Sebagaimana kita ketahui bersama, masyarakat Madura memiliki budaya yang unik dan unik dan itu menjadi identitas sendiri bagi masyarakat Madura, dan identitas budaya inilah yang dianggap sebagai identitas individu dan komunitas masyarakat Madura dalam tingkah laku dan kehidupannya. Mendengar kata Madura akan muncul pendapat negatif yaitu kasar, temperamen, arogan. Bahkan image yang lebih melekat bagi masyarakat di luar Madura adalah kerapan sapi dan budaya carok. Banyak orang telah mengetahui bahwa meskipun kelompok agama Islam pada umumnya memiliki pengetahuan yang utuh tentang ajaran agama Islam, ajaran Islam sendiri bertentangan dengan beberapa budaya di masyarakat, akan tetapi dalam kasus individu banyak orang masih berpegang pada gagasan mereka. Padahal, dari segi etos kerja, keuletan masyarakat Madura tergolong positif dan tidak di ragukan lagi. Kebanyakan dari mereka adalah orang-orang yang suka bekerja keras dan pantang menyerah, bahkan wanita pun di Madura tidak segansegan dan tidak canggung untuk bekerja keras dalam menunjang kebutuhan hidup ${ }^{5}$.

Orang Madura menganut Islam ortodoks. Makna Sunni dari Ortodoks Timur adalah ajaran standar dan diyakini mewakili kebenaran. Keluarga yang berhasil menunaikan kewajiban haji yang termasuk rukun Islam akan menikmati posisi mulia di mata masyarakat, sehingga menunaikan haji menjadi prioritas utama dalam kehidupan masyarakat Madura. Namun, banyak dari mereka mencari

\footnotetext{
${ }^{1}$ Iskandar D. Identitas Budaya Dalam Komunikasi Antar-Budaya: Kasus Etnik Madura dan Etnik Dayak.J Masy dan Budaya. 2004;6(2):119-140

2 Shodiqil A. Komunikasi Agama Dan Budaya (Studi atas Budaya Kompolan Sabellesen Berdhikir Tarekat Qadiriyah Naqshabandiyah di Bluto Sumenep Madura). Al-BAlaqh. 2016;1(2):161-182

${ }^{3}$ Sholichah IF. Dentitas Sosial Mahasiswa Perantau Etnis Madura. Psikosains. 2016;11(1):40-52

${ }^{4}$ Qamariah I. Kendari, Budaya Komunikasi Etnis Madura Dalam Kehidupan Sosial Di Kelurahan Mata Kota. Ilmu Sos dan Ilmu Polit. 2016;3(2):1-15

5 Madura I, Hefni M. Islam Madura . 2013;XIII:1-26
} 
perlindungan dari kekuatan supernatural yang melindungi roh jahat dan baik ${ }^{6}$. Dari segi permintaan, masyarakat Madura tergolong berpenghasilan rendah dan menengah. Di tempat-tempat di mana perawatan medis, gizi, makanan dan pendidikan masih sangat dibutuhkan peningkatan. Masyarakat Madura sangat membutuhkan pendidikan khususnya pendidikan vokasi agar dapat ikut serta dalam mengangkat pertumbuhan ekonomi dan perluasan industri yang sedang dilakukan khususnya di Pulau Madura. ${ }^{7}$

Bahkan masyarakat Madura sendiri dapat meningkatkan perekonomian melalui budaya, pariwisata dan masakannya ${ }^{8}$. Keunikan tradisi dan budaya Madura sangat memungkinkan untuk dipelajari dalam waktu yang lama, karena beberapa hal berbeda dengan daerah-daerah lain, seperti kerapan sapi yang menjadi identitas bagi Madura. Pulau garam yang ia kenal memiliki budaya yang cukup unik, dan identitas budaya inilah yang membedakan dengan daerah-daerah lain. Misalnya budaya Kerapan sapi salah satunya. Siapapun yang mendengar istilah kerapan sapi maka ia akan berfikir bahwa itu adalah budaya Madura. Kerapan sapi itu sendiri adalah ras atau ras lainnya. Namun keunikannya terletak pada mengapa kerapan sapi masih bisa bertahan hingga saat ini, karena umat manusia telah mengembangkan peradaban yang serba teknologi. ${ }^{9}$ Meski banyak orang yang menganggap kerapan sapi sebagai kegiatan rekreasi, hanya sedikit yang memiliki proporsi yang berlawanan dengan keberadaan budaya ini. Konon budaya asli Madura menyiksa hewan di sini dan menjadi tempat berjudi, bahkan setelah sekian lama berkelahi, solusinya adalah "ngomong sabit". Hal ini dapat memperkuat persepsi negatif bagi masyarakat di luar Madura. Arti carok sendiri dapat digunakan untuk mengembalikan harga diri (martabat) ketika orang lain menginjak-injaknya, yang berkaitan dengan harta benda, tahta, dan perempuan, maka carok tidak bisa di tawar lagi. Kuncinya adalah semuanya demi kehormatan.

Dalam ungkapan Madura "Lebbi Bhegus Pote Tolang etembhang Pote Mata". (Lebih baik mati (carok), daripada hidup karena malu). Selain itu, faktor terjadinya carok sendiri selalu didukung oleh lingkungan sosial. Menurut De Jonge, dalam penelitiannya tahun 1993, dari sudut pandang ini, semua ruang lingkup yang ada adalah ruang lingkup terencana. Menurut informasi yang diperoleh dari lokasi kejadian, terdapat juga beberapa sindiran spontan, yaitu ketika tiba-tiba terjadi perselisihan penyalahgunaan harga diri, salah satu pihak yang bersangkutan langsung menyerang (membunuh) pihak lainnya. Karena itu, Latief Wiyata juga mengemukakan dalam bukunya bahwa Nyekep sudah menjadi kebiasaan dan sulit sangat untuk ditinggalkan oleh warga Madura, terutama di kawasan peDesaan. Nyekep adalah bahasa Madura, artinya membawa senjata tajam yang tersembunyi di balik pakaian. Tampak jelas bahwa setiap kali mereka meninggalkan rumah atau bepergian pada pagi, siang atau sore hari, mereka hampir selalu membawa senjata

\footnotetext{
${ }^{6}$ Cahyanti I, Husniah F. Mitos dalam Ritual Ruwatan Masyarakat Madura di Kecamatan Gending Kabupaten Probolinggo (Myth of Ritual Ruwatan in Madura Society in District Gending Probolinggo). J EDUKASI. 2017;4(1):13-19

7 Moh Wardi. Pengembangan entrepreneurship berbasis experiential learning di pesantren Al-Amien Prenduan Sumenep dan Darul Ulum Banyuanyar Pamekasan. Diss. UIN Sunan Ampel Surabaya, 2017.

${ }^{8}$ Aminullah , Puji Lestari dan ST. Model Komunikasi Antarbudaya Etnik Madura. 2015;(274)

9 Permadani Y, Efendi P, Cahyono HB, Jember UM. Komunikasi Antarbudaya: Akulturasi Bahasa Dalam Masyarakat Pendalungan Kabupaten Jember. 2019;3(1):13-26.
} 
tajam. Apalagi saat mereka memang punya musuh. Dalam menghadapi perselisihan atau konflik yang mungkin terjadi kapan saja, dan di mana saja, mengembangkan kebiasaan untuk selalu siap melakukan sesuatu dengan berani, bahkan ada asumsi ketika masyarakat Madura mau keluar rumah ada yang tidak nyikep/tidak bawa senjata, orang tersebut di anggap sombong. Meski pemerintah sudah berupaya untuk melakukan larangan yang berbentuk peraturan atau bahkan pemenjaraan, namun masyarakat Madura tetap menutup telinga dengan aturan tertulis dan terkesan kurang efektif mengantisipasi munculnya carok, karna hal tersebut sudah termasuk bagian dari budaya yang terjadi di tengah-tengah masyarakat ${ }^{10}$.

Menurut Rozaki, Blater ditetapkan pada 2009 sebagai sesepuh masyarakat sekitar (Madura). Tidak semua orang bisa disebut bhajing, karena hanya orangorang tertentu yang bisa disebut "bhajing" dengan istilah ini. Julukan itu merupakan hasil dari penobatan komunitas tempat tinggal orang tertentu. Tentunya upacara penobatan-penobatan yang berbeda, sesuai dengan pengaruhnya, ada yang karena keberaniannya (kabhangalannah). Bagi masyarakat Madura, selain tokoh formal dan informal (kiyai), blater merupakan salah satu tokoh terpenting di Madura yang patut juga harus di perhitungkan, karna pengaruhnya sangat besar apalagi dalam catur perpolitikan. Dari sudut pandang sosial, penistaan agama dapat muncul dari kelas dan kelompok sosial manapun dalam masyarakat Madura. Baik di lingkungan dengan latar belakang sosial dan agama (santri) yang ketat, atau di lingkungan sosial yang lebih bersahabat. Sering juga ditemukan bahwa orang-orang yang sebelumnya menjadi santri di pesantren menjadi seorang blater. Blater yang berlatar belakang Santri ini biasanya sangat pandai mengaji dan membaca kitab-kitab kuning, bahkan dari perilaku dan tutur katanya sangat sopan. ${ }^{11}$

Bagi masyarakat Madura, pandai mengaji dan membaca kitab kuning bukan hal yang lazim lagi, karena pada umumnya dalam tradisi masyarakat Madura pendidikan agama melalui musholla, madrasah dan masjid sudah menjadi hal yang lumrah. Latar belakang inilah juga memungkinkan blater yang memiliki latar belakang Santri, memiliki jaringan budaya dan tradisional yang kaya untuk menghormati para kiyai. ${ }^{12}$ Blater juga sangat mewarnai dinamika politik Pulau Madura itu sendiri, bahkan bisa dikatakan bahwa politik di Madura dikontrol dua kelompok yaitu kelompok para kiyai dan para blater, hal ini sangat menarik karna ketika tokoh masyarakat lepas komunikasi dengan dua kelompok tersebut atau keluar dari lingkaran itu, maka kehidapun sosial di masyarakat tidak akan harmonis atau aman karna banyaknya pencuri yang dimobilisasi oleh salah satu kelompok masyarakat ${ }^{13}$.

Bahkan tidak sedikit para kades berlatar belakang blater yang sibuk bermain remo dengan blater di Desa lain, sehingga mereka malas mengurus Desanya. Bahkan, pada kasus terparah, sebagian kepala Desa membesarkan pencuri untuk kepentingannya sendiri khusunya para blater ini dimanfaatkan sebagai salah satu

\footnotetext{
10 Wahyudi M. MADURA: Masyarakat, Budaya, Media, Dan Politik.; 2015.

${ }^{11}$ Bakri H. Resolusi Konflik melalui Pendekatan Kearifan Lokal Pela Gandong di Kota Ambon Conflict Resolution toward Local Wisdom Approach of Pela Gandong in Ambon City. 2015;1(1):51-60

${ }^{12}$ Ismail, Ismai, and Moh Wardi. "PERAN KIAI DALAM REKONSILIASI SOSIAL PASCA CAROK MASSAL DI BUJUR TENGAH PAMEKASAN MADURA." IBDA: Jurnal Kajian Islam dan Budaya 17.1 (2019): 128152.
}

13 Utsman H. TENGKA : Etika Sosial Dalam Masyarakat Tradisional Madura.; 2018. 
kekuatan ketika kegiatan pilkada sebagai salah satu tameng atau pertahanan bagi para calon kepala Desa atau orang-orang yang sedang berkompetisi dalam kegiatan politik. Efek dari pilkades ini sangat besar berdampak pada keharmonisan kehidupan bermasyarakat, sehingga konflik antar masyarakat bahkan sesama saudara sangat tinggi, oleh karenanya kondisi yang seperti ini tidak boleh dibiarkan berkepanjang, maka disini dibutuhkan sebuah media untuk merekonsiliasi konfik yang terjadi di masyarakat pasca pilkades.

\section{Metode Penelitian}

Penelitian ini menggunakan metode penelitian kualitatif ${ }^{14}$. Penelitian kualitatif pada hakikatnya adalah mengamati orang dalam lingkungan hidupnya. Berinteraksi dengan masyarakat, dan berusaha untuk memahami bahasa dan tafsiran mereka terkait dengan kehidupan sekitarnya15. Dengan menggunakan metode kualitatif, maka data yang didapat akan lebih lengkap, lebih mendalam, kredibel, dan bermakna sehingga tujuan penelitian untuk mengetahui tentang tradisi timmong sebagai rekonsiliasi konflik pasca pilkada di kabupaten Sumenep tercapai.

Penelitian ini bertempat di Desa Batu Belah Barat kecamatan dauk kabupaten Sumenep. Tempat ini dipilih oleh penelitian sebagai lokasi penelitian disebabkan ketertarikan peneliti terhadap fenomena dan dampak tradisi di lokasi tersebut.

Orang madura yang tinggal di daerah ini memiliki pekerjaan dan tingkat pendidikan yang berbeda-beda, pemilihan sumber data ini memiliki tujuan, dan termasuk sumber utama yaitu para petua adat dan tokoh agama di masyarakat. Data sekunder berupa buku-buku tentang Madura, hasil penelitian tentang Madura, dan profil Desa secara umum, sedangkan yang menjadi instrumen dalam penelitian ini yaitu peneliti sendiri. Instrumen tersebut berupa laptop, kamera dan pemandu. Wawancara digunakan sebagai penunjang dan referensi untuk menjaring data dari hasil wawancara dan observasi untuk mempertajam dan menyempurnakan data.

Teknik dalam pengumpulan data yang dilaksanakan melalui sistem observasi, wawancara dan pencatatan. Teknik analisis data mengikuti konsep miles dan Huberman ${ }^{16}$, secara interaktif melakukan kegiatan analisis data kualitatif dan terus menerus dilakukan sehingga dapat menjenuhkan data yaitu reduksi data. Tampilan data dan verifikasi. Uji validasi data dengan memperluas ruang lingkup observasi, meningkatkan ketekunan dan triangulasi.

\section{Pembahasan dan Hasil Penelitian \\ Prosesi Tradisi "Timmong" di Desa Batu Belah Barat Kecamatan Dasuk Kabupaten Sumenep}

Tradisi timmong merupakan salah satu tradisi masyarakat Desa Batu Belah Barat kecamatan Dasuk kabupaten Sumenep. Tradisi ini dilaksanakan sebagai salah satu ritual untuk memanggil hujan dalam kata lain sebagai permohonan kepada

\footnotetext{
14 Mulyadi A. Memaknai Praktik Tradisi Ritual Masyarakat Muslim Sumenep. Endogami J Ilm Kaji Antropol. 2012;2(3):124-135.

${ }^{15}$ Sholichah IF. Dentitas Sosial Mahasiswa Perantau Etnis Madura. Psikosains. 2016;11(1):40-52

16 Nurif SMM. Peran Serta Masyarakat Bangkalan Dalam Mengusahakan Peningkatan Perekonomian. jsh J Sos Humaniora, Vol 4 No1, Juni 2011. 2011;4(1):84-95
} 
tuhan yang Maha Esa untuk mendatangkan hujan dan keberkahan bagi kehidupan masyarakat di saat kemarau. Tradisi ini berlangsung sejak masa lampau bahkan akar jejak awal mula tradisi ini, masyarakat Desa Batu Belah Barat kecamatan Dasuk ini terutama para pemangku budaya yaitu para sesepuh Desa sudah tidak mengetahui lagi awal mula kapan tradisi ini dimulai, hal tersebut dikarenakan minimnya masyarakat yang menulis / membukukan sejarah dari timmong itu sendiri. Dari hasil penelitian ini dengan harapan semoga bisa membantu masyarakat Batu Belah Barat untuk tetap bisa melestarikan budaya unik ini sampai kegenerasi berikutnya.

Tradisi timmong ini dilakukan di empat dusun tepatnya di makam leluhur yaitu yang disebut dengan bhujuk atau makam yang dikeramatkan oleh masyarakat Desa setempat, antara lain yaitu Bhujuk Ginang, Bhujuk Nogosari, dan Bhujuk Blimbing. Nama - nama dari Bhujuk ini pada awal mulanya di ambil dari sejarah dan keahlian dari masing-masing bhujuk yang diriwaayatkan oleh para sesepuh di Desa tersebut yang sampai saat ini masih dikeramatkan oleh masyarakat setempat.

Prosesi ritual acara timmong ini dimulai dengan musyawarah para sesepuh dan tokoh baik tokok masyarakat maupun tokoh agama di Desa atau di setiap dusun ketika musim tanam dimulai karena musim hujan yang jatuh tidak teratur sehingga muncul kekhawatiran masyarakat jika turun hujan tidak teratur maka tanamannya akan terancam rusak, sehingga keyakinan bagi masyarakat Desa tersebut khususnya para sesepuh dan para tokoh pemuga agama perlu untuk diadakan upacara ritual yang di sebut dengan ritual timmong. Upcara timmong diawali dengan mengumpulkan para personel atau anggota yang terdiri dari pemuda dan sesepuh yang dipilih secara khusus dan diberi tugas masing-masing tiap individu kemudian jika hal tersebut sudah disepakati hari dan tanggalnya, maka prosesi tersebut dapat dilanjutkan.

Pada waktu yang ditentukan anggota yang terdiri dari 25 orang sampai dengan 50 orang yang bertugas dalam melakukan ritual timmong mendatangi makam leluhur (bhujuk) yang dianggap keramat tersebut, dengan diiringai rombongan masyarakat lain yang membawa berbagai macam makanan seperti nasi, lauk pauk, jajanan, dan sebagainya. Kegaiatan ini dimulai dengan pemuka agama memberikan pegantar tentang maksud dan tujuan dilaksanakan prosesi timmong tersebut dilanjutkan dengan membaca do'a bersama dengan membaca surat yasin, tahlil, dan kemudian do'a-do'a yang ditujukan kepada leluhur Desa tersebut. Di sela-sela do'a maka dimulai prosesi timong dengan urutan semua anggota timmong yang sudah dipilih dengan posisi berdiri dan duduk melingkar dengan di iringi tarian-tarian khusus sambil membaca bacaan yang lebih mirip seperti musik yang disuarakan dengan mulut atau verbal secara bergantian dengan setiap orang melafalkan bunyi yang berbeda-beda sehingga membentuk musik, bacaan utamanya seperti bunyi "karatuk timmang", "karatuk nang-nong", "hek-hik", "pakjetong", dan bacaan-bacaan lain yang di sesuaikan dengan irama, kemudian setelah dapat beberapa putaran dengan bacaan yang sudah ditugaskan setiap personel lalu istirahat di tempat sejenak kemudian dilanjutkan kembali dengan berdiri lagi sambil menyuarakan bacaan-bacan lain seperti "sandur lillang" dan ditutup dengan "alisonnar". Ketika bacaan "alisonnar" dibacakan, maka menandakan bahwa prosesi ini telah selesai. Kemudian dilanjutkan dengan do'a bersama yang dipimpin oleh pemuka agama atau 
yang disebut dengan kyai yang di amiini oleh masyarakat yang hadir, dilanjutkan dengan makan bersama. Makanan tersebut dibawa oleh masyarakat kemudian diletakkan di tanah yang diberikan alas dari tikar untuk saling bertukar makanan, dilanjutkan makan bersama, acara ini diakhiri dengan saling bersalaman untuk saling meminta maaf dan memaafkan. Dengan harapan semua dosa dan kesalahan masyarakat dapat terhapus, termasuk konflik sosial yang terjadi akibat pilkades.

Anehnya dan ini di yakini oleh masyarakat Desa Batu Belah Barat bahwa ketika ritual timmomg ini tidak dilaksanakan maka akan berakibat fatal atau berdampak negatif pada kehidupan masyarakat di Desa Batu Belah Barat seperti halnya bidang pertanian masyarakat yang tidak berhasil atau dengan kata lain gagal, sehingga hasil dari pertanian ini dikatakan $t a^{\prime}$ bharkat atau tidak barokah, selain dari itu hal ini juga di yakini sangat berdampak pada ketentraman kehidupan masyarakat setempat yang tidak normal dan terganggu karena banyaknya macam musibah dan ujian yang di hadapi masyarakat setempat akibat dari tidak dilaksanakannya ritual tersebut. Jadi berangkat dari keyakinan ini masyarakat setempat tidak punya alasan lagi untuk tidak melaksanakan ritual timmong. Sehingga ritual ini rutin dilaksanakan setiap tahun.

\section{Tradisi “Timmong" Sebagai Rekonsiliasi Dampak Sosial Pasca Pilkades di Kabupaten Sumenep}

Munculnya konstelasi politik di berbagai daerah mulai dari pusat sampai ke Desa merupakan dampak dari dinamisnya kehidupan politik di Indonesia, hal ini juga berdampak di Desa Batu Belah Barat kecamatan Dasuk kabupaten Sumenep.

Dimulai dari pemilihan presiden, pemilihan dewan perwakilan rakyat RI (DPR-RI), Dewan Perwakilan Rakyat Daerah Propinsi (DPRD-Propinsi), dan dewan perwakilan rakyat derah kabupaten (DPRD-Kabupaten), pemilihan Bupati dan terakhir pemilihan kepala Desa seringkali menimbulkan konflik yang berujung pada perpecahan di kalangan masyarakat semuanya terjadi karena bedanya persepsi yang membuat terbelah dalam berbagai pilihan, hal ini seringkali menimbulkan konflik internal di dalam masayrakat, bahkan yang lebih sadis lagi timbulnya perselisihan atau konflik di dalam keluarga khususnya jika ada persaingan yang tidak sehat dalam kontetasi politik dengan menggunakan politik uang dan memanfaatkkan para bhajing atau blater. Terlebih jika calon yang menjadi jagoan adalah warga dari Desa tersebut maka akan semakin naik tensi suasana politik di Desa tersebut.

Konflik ini dapat berakibat pada masyarakat yang sebelumnya hidup tentram, harmonis menjadi tegang dan saling bersaing dalam segala bentuk aspek untuk mendapatkan dukungan dalam mencapai tujuannya masing-masing baik dalam berkelompok maupun secara individu sehingga seringkali merusak tatanan ketentraman masyarakat Desa sampai dengan dalam keluarga rumah tangga hanya karena faktor perbedaan pilihan. hal ini akan berkelanjutan bahkan bisa dikatakan menjadi dendam sejarah yang tidak akan mudah dilupakan sampai anak cucunya, efek ini sangat berdampak dengan waktu yang cukup lama meskipun kontelasi politik tersebut telah usai, namun konflik yang terjadi di masyarakat masih tetap memendam dan tidak mudah untuk kembali pada keadaan semula yang aman dan tentram. 
Dengan munculnya tradisi timmong ini menjadi satu-satunya media untuk menggugah hati masyarakat Desa Batu Belah Barat bisa berkumpul lagi, duduk bersama untuk menyelesaikan segala bentuk masalah termasuk di akibatkan dari efek pilkades dengan satu kepentingan yaitu kemaslahatan, kemakmuran dan keberkahan masyakat Desa dalam menjalani kehidupan. Maka berbagai macam dari golongan masyarakat yang terbelah tersebut kemudian bersama-sama bermusyawarah, berembuk bersama menyatukan persepsi untuk membentuk satu kepanitiaan agar acara tersebut dapat dilaksanakan dengan lancar tanpa suatu kendala.

Hal ini sangat berdampak positif bagi masyarakat yang sebelumnya terpecah karena adanya konflik efek dari perbedaan pandangan dan pilihan politik akibat pilkades, dengan kegiatan tradisi timmong ini masyarakat yang terbelah tersebut melakukan rekonsiliasi atau menjadi satu kembali karena satu kepentingan bersama, dengan lestarinya budaya timmong, maka masyarakat Desa Batu Belah Barat dapat senantiasa menjaga kerukunan dan ketentraman Desa dalam menjalani kehidupan.

\section{kesimpulan}

Tradisi timmong merupakan tradisi masyarakat Desa Batu Belah Barat kecamatan Dasuk kabupaten Sumenep jawa timur. Tradisi timong merupakan acara ritual yang dilakukan oleh masyarakat untuk memohon hujan kepada Tuhan Yang Maha Esa agar tanaman di ladang masyarakat dapat tumbuh subur dan tidak kekeringan, selain itu tujuan dari acara ritual ini untuk kesejahteraan dan keselamatan masyrakat Desa Batu Belah Barat kecaamata Dasuk, tradisi ini dumulai dengan mengadakan musyarawarah yang dipimpin oleh pemuda Desa, tokoh masyarakat dan dilaksanakan oleh 25-50 anggota dengan melakukan tarian dan menyuarakan bunyi-bunyian tertentu secara bergantian sehingga membentuk seperti alunan musik, kemudian dilanjutkan dengan do'a bersama dan makan bersama, lalu ditutup saling bersalaman untuk saling memaafkan. Anehnya ini di yakini oleh masyarakat Desa Batu Belah Barat bahwa ketika ritual timmomg ini tidak dilaksanakan maka akan berakibat fatal atau berdampak negatif pada kehidupan masyarakat desa batu belah Barat seperti pertanian masyarakat gagal, selain itu hal ini juga di yakini sangat berdampak negatif pada kehidupan masyarakat setempat akibat dari tidak dilaksanakannya ritual tersebut. Jadi berangkat dari keyakinan ini masyarakat setempat tidak punya alasan lagi untuk tidak melaksanakan ritual timmong. Sehingga ritual ini rutin dilaksanakan setiap tahun.

Moment tradisi timmong ini sangat terasa dan efektif sebagai salah satu cara atau mediasi bagi masyarakat agar masyarakat Desa Batu Belah Barat kecamatan Dasuk yang pada amulanya terjadi konflik dan membentuk golongan kembali normal dan rukun, bersatu untuk kepentingan bersama atau kemaslahatan bersama pasca pilkada yang seringkali menimbulkan ketidakharmonisan masyarakat, maka tradisi budaya ini dapat dijadikan sebagai salah satu media dan solusi dalam rekonsiliasi konflik yang terjadi di masyarakat Batu Belah Barat pasca moment politik pilkades. 


\section{DAFTAR PUSTAKA}

Aminullah , Puji Lestari dan ST. Model Komunikasi Antarbudaya Etnik Madura. 2015;(274).

Ali M. Akomodasi Nilai-Nilai Budaya Masyarakat Madura Mengenai Penyelesaian Carok Dalam Hukum Pidana. URNAL Huk. 2016;17(1):85-102.

Bakri H. Resolusi Konflik melalui Pendekatan Kearifan Lokal Pela Gandong di Kota Ambon Conflict Resolution toward Local Wisdom Approach of Pela Gandong in Ambon City. 2015;1(1):51-60.

Iskandar D. Identitas Budaya Dalam Komunikasi Antar-Budaya: Kasus Etnik Madura Dan Etnik Dayak. J Masy Dan Budaya. 2004;6(2):119-140.

Ismail, Ismai, and Moh Wardi. "PERAN KIAI DALAM REKONSILIASI SOSIAL PASCA CAROK MASSAL DI BUJUR TENGAH PAMEKASAN MADURA." IBDA: Jurnal Kajian Islam dan Budaya 17.1 (2019): 128-152.

Shodiqil A. Komunikasi Agama Dan Budaya (Studi Atas Budaya Kompolan Sabellesen Berdhikir Tarekat Qadiriyah Naqshabandiyah Di Bluto Sumenep Madura). AlBalaqh. 2016;1(2):161-182.

Sholichah IF. Dentitas Sosial Mahasiswa Perantau Etnis Madura. PSIKOSAINS. 2016;11(1):40-52.

Madura I, Hefni M. Islam Madura . 2013;XIII:1-26.

Cahyanti I, Husniah F. Mitos Dalam Ritual Ruwatan Masyarakat Madura Di Kecamatan Gending Kabupaten Probolinggo (Myth Of Ritual Ruwatan In Madura Society In District Gending Probolinggo). J EDUKASI. 2017;4(1):13-19.

Permadani Y, Efendi P, Cahyono HB, Jember UM. Komunikasi Antarbudaya: Akulturasi Bahasa Dalam Masyarakat Pendalungan Kabupaten Jember. 2019;3(1):13-26.

Utsman H. Tengka : Etika Sosial Dalam Masyarakat Tradisional Madura.; 2018.

Mulyadi A. Memaknai Praktik Tradisi Ritual Masyarakat Muslim Sumenep. Endogami J Ilm Kaji Antropol. 2012;2(3):124-135.

Nurif SMM. Peran Serta Masyarakat Bangkalan Dalam Mengusahakan Peningkatan Perekonomian. jsh J Sos Humaniora, Vol 4 No1, Juni 2011. 2011;4(1):84-95.

Qamariah I. Kendari, Budaya Komunikasi Etnis Madura Dalam Kehidupan Sosial Di Kelurahan Mata Kota. Ilmu Sos dan Ilmu Polit. 2016;3(2):1-15.

Wahyudi M. Madura: Masyarakat, Budaya, Media, Dan Politik.; 2015.

Wardi. Moh. Pengembangan entrepreneurship berbasis experiential learning di pesantren Al-Amien Prenduan Sumenep dan Darul Ulum Banyuanyar Pamekasan. Diss. UIN Sunan Ampel Surabaya, 2017. 